\title{
ANALISIS PETA POLITIK KANDIDAT CALON GUBERNUR DAN ARAH KOALISI PADA KONTESTASI PEMILIHAN GUBERNUR JAWA TIMUR 2018
}

\author{
Yusuf Adam Hilman \\ Program Studi Ilmu Pemerintahan, Universitas Muhammadiyah Ponorogo, Jawa Timur \\ E-adamhilman@umpo.ac.id
}

\begin{abstract}
ABSTRAK
Pada pemilihan kepala daerah (Pilkada) Jawa Timur 2018, terdapat dua koalisi partai yang koheren dengan budaya lokal dan dukungan massa yang besar. Di satu pihak, Khofifah dan Emil Dardak diusung oleh: Partai Demokrat, Partai Nasional Demokrasi, Partai Persatuan Pembangunan, Partai Hanura, Partai Golongan Karya, Partai Amanat Nasonal, dan Partai Gerakan Indonesia Raya. Di pihak lain, Syaifullah Yusuf dan Puti Guntur Soekarno diusung oleh Partai Kebangkitan Bangsa, Partai Demokrasi Indonesia Perjuangan, dan Partai Keadilan Sejahtera. Kontestasi tersebut menarik untuk diamati mengingat Jawa Timur merupakan provinsi yang memiliki keunikan budaya yang beragam dan sangat menghargai budaya lokal. Terlebih lagi, kedua kandidat tersebut sama-sama memiliki peluang untuk memenangkan pemilu. Artikel ini mencoba untuk menggambarkan peluang kemenangan masing-masing kandidat melalui pemetaan yang terkait dengan kekuatan, kelemahan, peluang, dan ancaman. Kajian ini dibangun dengan metode kualitatif deskriptif untuk menguraikan pemetaan politik menjelang Pilkada. Koalisi-koalisi yang dibentuk memiliki kans kemenangan yang sama. Namun, hanya mereka yang mampu membaca dan memahami kondisi masyarakat, termasuk budayanya, dan karakteristik komunitas yang memiliki keunggulan pada Pilkada.
\end{abstract}

Kata kunci: Demokrasi, kandidat, pemilihan kepala daerah, Jawa Timur.

\section{POLITICAL MAPPING ANALYSIS OF GOVERNOR CANDIDATE AND ITS COALITION PROJECTION IN THE 2018 EAST JAVA REGIONAL HEAD ELECTION}

\begin{abstract}
In the head of East Java province election in 2018, there are two party coalitions which coherent with local culture and also the mass base support. On the one side, Khofifah and Emil Dardak carried by: Partai Demokrat, Paratai Nasional Demokrasi, Partai Persatuan Pembangunan, Partai Hanura, Partai Golongan Karya, Partai Amanat Nasonal, dan Partai Gerakan Indonesia Raya. On the other side, Syaifullah Yusuf and Puti Guntur Soekarno backed by: Partai Kebangkitan Bangsa, Partai Demokrasi Indonesia Perjuangan, dan Partai Keadilan Sejahtera. The contestation is interesting to be scrutinized considering that East Java province has unique cultural diversity and favor the local values. Moreover, those pairs of candidates have the same potency to win the election. This article tries to scrutinize the opportunities of each candidate's chance through mapping of related strengths, weaknesses, opportunities, and threats. This research uses descriptive qualitative methodin describing the political map heading the elections. The coalitions that is formed has the same opportunities. However, those who comprehend and read the internal conditions of the community, including its culture, and community characteristics, could be able to excel in the election.
\end{abstract}

Key words: Democracy, candidate, regional head election, East Java.

\section{PENDAHULUAN}

Praktik pemilihan umum (Pemilu) seringkali diwarnai dengan berbagai macam dinamika serta konflik. Seperti penyelenggaraan pemilihan kepala daerah di Provinsi DKIJakarta, pergolakan terjadi dan memberikan dampak pada Pilkada di daerah lainnya. Berawal dari statement Gubernur Incumbent Basuki Tjahaya
Purnama (Ahok) yang dianggap melecehkan umat Islam dan kasus tersebut kemudian menjadi isu nasional (Herdiansah, et al., 2017).

Fenomena Pilkada DKI Jakarta bisa menjadi pembelajaran bagi praktik penyelenggaraan pemilu di Indonesia, terutama terkait dinamika serta konflik pelaksanaan pesta demokrasi yang sarat kepentingan dan sensitif. Pelajaran berharga dari Pilkada DKI Jakarta 
2017 juga terkait dengan penggunaan isu SARA, keberpihakan institusi terhadap calon, perang program, pencitraan kandidat, dan juga tindakan yang saling jegal hingga praktik politik uang. Namun, semua cara tersebut sebenarnya merupakan realitas sering digunakan sebagai strategi untuk pemenangan calon di hampir semua daerah.

Provinsi Jawa Timur merupakan salah satu daerah yang akan melaksanakan Pilkada untuk memilih Gubernur pada tahun 2018. Daerah ini memiliki akar sejarah yang kuat terutama terkait budaya dan jumlah massa fanatik. Pergolakan itu sudah mulai terlihat dan terekam dalam beberapa kegiatan yang melekat pada lembaga ataupun perseorangan. Fenomena yang muncul ke permukaan memang belum terlihat jelas, namun demikian isu-isu politik mulai meramaikan berbagai kegiatan di Jawa Timur. Rumor-rumor yang berkembang telah banyak membawa pengaruh dan mengindikasikan bahwa persaingan politik di daerah ini menarik perhatian secara nasional (Kpujatim.go.id, 3 Mei 2016).

Agenda Pemilihan Gubernur Provinsi Jawa Timur yang diselenggarakan pada tahun 2018 disertai berbagai agenda politik, mulai dari bentuk promosi dan juga pencitraan beberapa figur yang digadang akan maju. Jauh sebelum penentuan calon, sudah banyak yang memperlihatkan eksistensinya, sehingga dinamika politik mulai kentara ke permukaan. Dalam bursa calon Gubernur (Cagub) dan calon Wakil Gubernur(Cawagub) Jawa Timurterdapat beberapa kandidat yang dianggap mempunyai kapabilitas dan peluang untuk diusung seperti yang tertuang pada tabel di bawah. Namun demikian, data tersebut masih merupakan gambaran secara umumdan juga disarikan dari opini yang berkembang di masyarakat.

Bursa Cagub dan Cawagub di atas menampilkan 10 kandidat yang memiliki kualifikasi dan berbagai pertimbangan.Tetapi, berbagai kemungkinan masih bisa terjadi mengingat peta politik di Jawa Timur sulit diprediksi. Akan tetapi disini penulis melihat realitas yang paling rasional. Berdasarkan tabel dan rangking Cagub dan Cawagub tersebut, tentunya ada dua sosok yang bertengger di peringkat 1 dan 2, yakni Syaifullah Yusuf yang merupakan Wakil Gubernur Jatim, Khofifah Indar Parawangsa yang pada waktu itu menjabat Menteri Sosial RI. Jika di telisik lebih dalam, dua kandidat tersebut memiliki rekam jejak kompetisi panjang saat Pilgubdua periode sebelumnya. Selain itu, kedua kandidat merupakan mantan pengurus Gerakan Pemuda Anshor dan juga Muslimat Nahdlatul Ulama (NU), dimana kedua organisasi tersebut merupakan organisasi yang berada dibawah naungan NU yang memiliki basis masa terbesar di Jawa Timur.

Berkaca pada pengalaman sejarah dari dua kandidiat tersebut, merekalah yang diperkirakan paling memungkinkan mengikuti kontestasi Pilgub Jawa Timur 2018, namun demikian, peluang dan juga kesempatan harus bisa di petakan mengingat faktor figur saja tidak cukup untuk maju dalam sebuah kompetisi. Kondisi Jawa Timur memiliki peta kekuatan partai politik yang berbeda di tiap daerahnya, provinsi ini sendiri sangat luas terdiri dari sekitar

\section{Tabel 1. Bursa Cagub dan Cawagub Jatim}

\begin{tabular}{clll}
\hline No & \multicolumn{1}{c}{ Nama } & \multicolumn{1}{c}{ Pasangan Cagub } & Pasangan Cawagub \\
\hline 1 & Syaifullah Yusuf & $33,17 \%$ & $34,90 \%$ \\
2 & Khofifah Indar Parawangsa & $28,31 \%$ & $21,10 \%$ \\
3 & Tri Rismaharini & $26,13 \%$ & $21,50 \%$ \\
4 & AzwarAnas & $1,01 \%$ & $5,80 \%$ \\
5 & Agus Harimurti Y & $3,69 \%$ & $5,50 \%$ \\
6 & Said Abdullah & $3,85 \%$ & $4,20 \%$ \\
7 & Halim Iskandar & $1,51 \%$ & $2,70 \%$ \\
8 & M. Misbakhun & $0,50 \%$ & $2,20 \%$ \\
9 & Hasan Aminuddin & $1,34 \%$ & $1,50 \%$ \\
10 & Rendra Kresna & $0,50 \%$ & $0,70 \%$ \\
\hline
\end{tabular}

Sumber: The Intiactive Institute dalam Jawapos.com, 28 April 2017. 
33 kabupaten dan Kota. Di samping itu, aspek budaya dan corak kehidupan masyarakatnya yang unikmemerlukan pemetaan yang detail, agar bisa mendesain sebuah strategi kampanye yang relevan dan juga efektif di akar rumput.

Sinyal majunya kedua kandidat dengan poling teratasyang di realease oleh media memberikan penegasan bahwa kedua calon inilah yang paling kuat basis pendukungnya untuk bersaing merebutkan kursi gubernur. Kedua kandidat tersebut dalam Pilkada sebelumnya juga bertarung dengan sengit. Melihat fenomena tersebut, pemetaan terhadap peluang untuk memenangkan kursi kepala daerah Jawa Timur menarik dilakukan, sehingga terbentuk invetarisasi peta kekuatan politik dari kedua calon. Upaya ini juga diarahkan sebagai referensi terhadap tim pemenangan, supaya dapat membuat strategi pemenangan, dari hasil analisis yang menjadi kekuatan dan juga peluang serta kelemahan. Hal ini tentunya terkait erat dengan budaya masyarakat, koalisi partai pengusung calon, hasil pilkada yang telah lalu, dan juga daerah persebaran suara yang ada di Jawa Timur. Disini kemudian akan ada gambaran secara detail dan jelas, terkait peluang pemenangan Pilkada Jawa Timur 2018.

Rumitnya kondisi masyarakat dalam konteks pemetaan politik membuat hal tersebut sangat erat kaitannya dengan budaya politik yang ada di masyarakat Jawa Timur. Hal ini disusun berdasarkan perilaku politik masyarakat, dimana masyarakat memiliki pertimbangan khusus ketika menentukan pilihan dalam Pilkada. Karena itu, analisis kekuatan untuk memetakan peluang dari kandidat dalam pemilihan gubernur di Provinsi Jawa Timur sangat penting dilakukan. Hal ini yang kemudian harus dipikirkan tim pemenangan calon, agar pemetaan yang dibuat harus sebisa mungkin relevan dengan cara berfikir dan keyakinan masyarakat yang kadang cenderung tersegmentasi.

Dalam penelitian budi Mulyana pada januari 2015, budaya politik Indonesia dikatakan sebagai mixed political culture, sebuah kombinasi dari 3 (tiga) budaya politik, yaitu budaya parokial sebanyak 20 persen yang berasal dari masyarakat miskin, pendidikan rendah, terpencil dan suku terasing, budaya politik partisipan 16 persen, dari kalangan sarjana, mahasiswa, elit politik perkotaan dan elit desa, dan budaya politik subyek sebesar 60 persen dari kalangan kelas menengah perkotaan dan massa pedesaan (Rasaili, 2016).

Sementara konsepsi budaya politik parokialbiasa dilakukan orang yang apatis terhadap kehidupan politik. Budaya politik subyek yang sangat tersegmentasi hanya membela kalangan sendiri yang akan bereaksi ketika mereka memperoleh keuntungan atau berdampak kepada mereka. Budaya politik patisipan merujuk kepada masyarakat yang mempunyai kesedaran politik yang tinggiatau yang disebut civil society (Hamil, 2011)

Perilaku yang muncul pada masingmasing individu dalam memilih mempunyai pertimbangan-pertimbangan tertentu untuk menentukan sebuah keputusan. Di dalam diri masing-masing pemilih terdapat dua orientasi, yaitu: orientasi policy-problem solving dan ideology. Ada beberapa pendekatan untuk melihat perilaku pemilih: pendekatan sosiologis, psikologis, rasional dan domain kognitif.

Kondisi tersebut pada akhirnya mengarahkan penulis untuk melakukan kajian yang lebih mendalam dari berbagai sumber, guna menjawab persoalan mengenai Pilkada di Jawa Timur. Terdapat beberapa rumusan masalah yang ingin diungkap, diantaranya bagaimana peta politik yang terbentuk dari perkembangan kondisi sosial masyarakat yang ada di Jawa Timur dalam menghadapi Pilkada 2018? Kemudian berapa besar peluang kandidat yang akan maju dalam Pilkada Jawa Timur?

\section{METODE}

Dalam menjawab rumusan masalah di atas, tulisan ini menggunakan pendekatan kualitatif deskriptif. Penelitian kualitatif sering juga dinamakan pendekatan yang humanistik karena didalam pendekatan ini cara pandang, cara hidup, selera ataupun ungkapan emosi dan keyakinan dari masyarakat yang diteliti berkenaan dengan masalah yang diteliti, juga termasuk data yang harus dikumpulkan (Liliana, 2014).

Jenis data dalam tulisan ini antara lain hasil survei, surat kabar, dokumen, dan juga hasil penelitian lainnya. Data yang dikumpulkan kemudian diolah dan dikodifikasikan kemudian dianalisis. Hasilnya kemudian dijadikan sebagai dasar untuk memetakan kekuatan dan peluang untuk maju sebagai gubernur Jawa Timur 2018. Analisis data juga dilakukan melalui metode 
trianggulasi sebagai teknik pemeriksaan keabsahan data dengan cara memanfaatkan sesuatu yang lain di luar data untuk keperluan pengecekan atau sebagai pembanding terhadap data (Bachri, 2010).

\section{HASIL DAN PEMBAHASAN}

\section{Budaya Politik Masyarakat di Jawa Timur}

Jawa Timur merupakan daerah yang unik karena luas wilayahnya yang terdiri dari 38 kabupaten dan kota.Daerah ini juga memiliki pola, corak, serta budaya yang berbeda yang dapat dilihat dalam kehidupan keseharian masyarakat yang masih memegang erat keyakinan, termasuk dalam kehidupan bermasyarakat, bernegara dan berpolitik.

Secara tipologi, wilayah kebudayaan di Jawa Timur terbagi menjadi beberapa, yaitu: 1) kebudayaan Arek, kebudayaan Jawa Mataraman, kebudayaan Madura, dan kebu-dayaan Pandhalungan (kompas.com,13 Mei 2017). Provinsi Jawa Timur secara geografis memiliki keterkaitan dengan beberapa budaya, yakni Jawa, Madura, dan Baliyang terdiri dari wilayah pesisir dan juga pedalaman, sehingga membentuk alkulturasi budaya (Wurianto, 2012).

Entitas etnis Madura di Jawa Timur mememiliki karakteristik yang unik yakni stereotipikal, dan stigmatik, sehingga orang Madura memiliki realitas sosial yang sangat kuat. Dengan sikap ketaatannya, sifat tunduk, serta pasrah secara hierarkis kepada empat figur utama dalam berkehidupan, terlebih lagi dalam praktik keberagamaan. Keempat figur itu adalah Buppa, Babbu, Guru, dan Rato (Ayah, Ibu, Guru, dan Pemimpin pemerintahan) (Taufiqurrahman 2007).

\section{Gambar 2. Persebaran Wilayah Provinsi Jawa} Timur

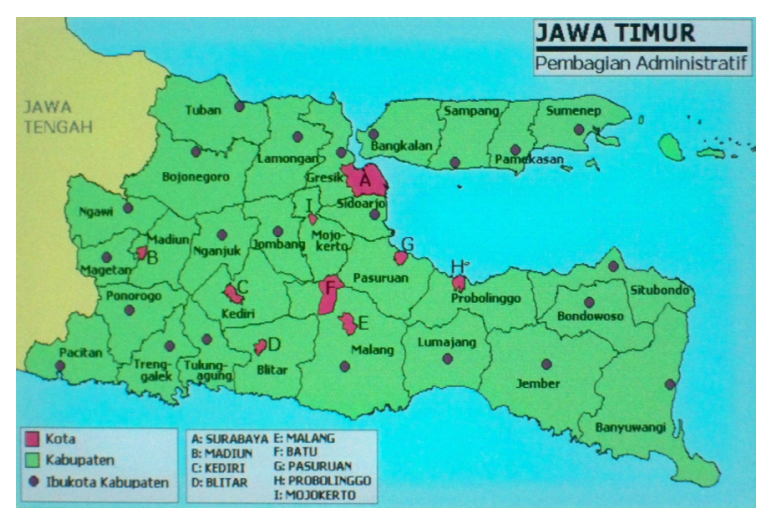

Sumber dari: BPS Jawa Timur 2017 diakses pada 18 Mei 2018
Melihat peta tlatah budaya di Provinsi Jawa Timur, kemudian kita akan lebih memahami tipologi serta historis wilayah tersebut, sehingga akan menimbulkan kecenderungan yang membuat masyarakat di Jawa Timur yang condong kepada organisasi sosial dan organisasi politik tertentu, misalnya NU dan PDIP. Karakteristik budaya Jawa Mataraman sangat kental dengan spirit nasionalisme, yang terkadang identik dengan sosok Sukarno yang mendirikan partai dengan spirit nasionalisme. Sosok Sukarno saat ini identik dengan Megawati yang mendirikan PDIP. Partai tersebut memiliki masa fanatik dibeberapa wilayah yang memiliki corak kebudayaan jawa Mataram dan juga Arek sepeti Surabaya, Malang, Blitar, Kediri, Madiun, dan Nganjuk.

Sejauh ini, PDIP selalu yakin bisa memperoleh kemenangan pada pilkada di Provinsi Jawa Timur. Hal ini menandakan bahwa PDIP cukup dominan di Jawa Timur. Dari 19 daerah, 13 wilayah telah dimenangkan pasangan calon yang diusung partai berlambang banteng itu (beritasatu.com, 19 Desember 2015).

Corak yang berikutnyaadalah karakteristik budaya Madura dan masyarakat pesisir. Modelnya secara umum masyarakat ini sangat religius dan memegang kuat budaya patron, sehingga membentuk model masyarakat yang sangat bersahaja. Karakteristik tersebut akhirnya membuat model tlatah ini sangat lekat dengan budaya pesantren, sedangkan afiliasi organisasi yang paling dominan adalah NU. Selain itu, masyarakat tlatah ini sangat menghargai dan menghormati para tokoh agama (kiai) dengan cara memuliakannya.

Nahdatul Ulama besar dan lahir di Jawa Timur. Selain itu banyak tokoh politik dan pemuka agama yang dilahirkan NU. Kenyataan historis tersebut telah membawa NU pada keikutsertaan dalam dunia melalui beberapa tokohnya dengan berbagai gagasan, sehingga mampu mempengaruhi para pendukung atau simpatisannya (Ja'far, 2012).

Posisi kiai dengan berbagai frasa, menjadi salah satu bentuk perubahan sosia, yang terkait dengan status sosial, dimana peranan kiai saat ini tidak lagi hanya berkutat pada urusan surgawi atau keagamaan tetapi juga urusan duniawi seperti politik (Abdurrahman, 2009).

Kultur Politik Masyarakat yang sudah digambarkan diatas, memberikan identifikasi 
terhadap pola keberpihakan masyarakat yang ada di provinsi Jawa Timur. Dengan model yang digambarkan seperti: "buah semangka" seperti pendapat Siti Zuhro Pengamat LIPI, luarnya hijau dan dalamnya merah, itu merupakan simbol bahwa hijau identik dengan budaya religius yang dimaksud disini adalah NU dan merah identik dengan organisasi nasionalis yang di maksud disini adalah PDIP (kompas.com, 02 Mei 2014).

Penggambaran tentang tlatah budaya di Jawa Timur, jika dikaitkan dengan peta politik terkait dengan besaran suara, hasilnya akan dapat terlihat, seperti gambar dibawah ini. Jumlah yang terekam dari data tersebut tampak persebaran proporsi suara sebagai berikut: wilayah Jawa Mataraman sebesar $40 \%$, wilayah Arek sebesar 27\%, wilayah Pandhalungan sebesar $24 \%$, wilayah Madura sebesar $9 \%$ (kompas.com, 21 Juli 2008).

\section{Gambar 3. pesebaran suara menurut tlatah kebudayaan Jawa Timur}

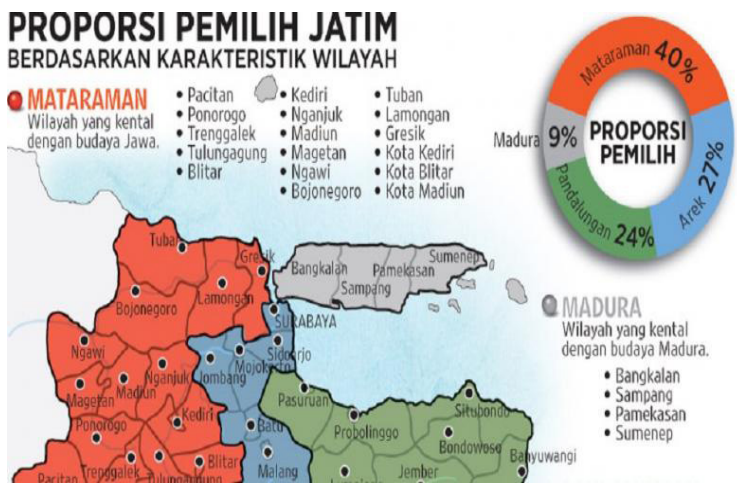

Sumber:kompas.com, diakses pada 18 Mei 2018.

\section{Isu strategis sebagai komoditas Politik}

Isu politik terkait Pilgub 2018 provinsi Jawa Timur, menjadi komoditas penting, mengingat isu tersebut akan dijadikan isu politik dari beberapa kandidat. Terdapat beberapa komoditas yang kemudian menjadi isu penting dalam kontes Pilkada, diantaranya keterlibatan Pemerintah Provinsi Jawa Timur ditandai denganturun nya SK Gubernur No. 188/113/KPTS/013/2012 Tentang Penegasan Batas Wilayah yang menyebutkan Gunung Kelud masuk wilayah Kabupaten Kediri yang menimbulkan konflik baru. Surat keputusan tersebut tidak menyelesaikan konflik dan menimbulkan konflik baru (Paradhisa, 2012).

Di samping itu, ada faktor politik yaitu adanya dugaan penarikan suara masyarakat Kabupaten Kediri untuk Gubernur terpilih
Sukarwo-Saefullah Yusuf, pasalnya pasangan petahana ini seolah-olah lebih berpihak dan menguntungkan Kabupaten Kediri. Berangkat dari pendapat tersebut, memang turunnya SK Gubernur tersebut sangat kental nuansa politik, karena pada waktu itu berdekatan dengan penyelenggarakan Pilgub Jawa Timur (Sari, 2014).

Indikasi-indikasi tersebut mengarah pada terbukanya konflik dalam Pilkada tahun 2018. Apalagi peta koalisi menempatkan kedua tokoh dalam kubu yang berbeda. Hal ini tentu akan menjadi salah satu komoditas untuk menjegal salah stau kandidat, sehingga berpotensi menjadi isu besar yang bisa menggiring opini publik terhadap para kandidat tersebut. Kasus sengketa perebutan kepemilikan Gunung Kelud antara Blitar dengan Kediri tentu bukan hanya persoalan potensi alam, namun demikian isu ini diprediksiakan menjadi salah satu komoditas politik para pasangan calon gubernur untuk menarik simpati masa mengingat proses hukum juga masih berjalan hingga saat ini. Perlu diketahui bahwa kedua wilayah ini merupakan basis massa dari PDIP, ini tentu sangat menarik karena bisa saja wilayah ini akan coba dijajaki oleh partai atau kandidat dari luar partai tersebut.

Isu yang kedua adalah kepemimpinan perempuan. Isu ini sebenarnya sudah mengalir deras ke permukaan ketika Pilkada sebelumnya, sehingga akan menghambat salah satu calon kandidat yang kebetulan pada periode mencalonkan diri kembali. Berkembang isu terkait penolakan terhadap pemimpin perempuan tersebut dibantah oleh Rais Syuriyah Pengurus Wilayah Nahdlatul Ulama (PWNU) Jawa Timur KH Miftakhul Achyar. Hal ini terkait dengan akan majunya Ketua Umum Pengurus Pusat Muslimat NU Khofifah Indar Parawansa sebagai Calon Gubernur Jatim (Nu.or.id, 18 April 2018).

\section{Hasil Pilgub 2013 dan Kondisi Politik Terkini}

Provinsi Jawa Timur menampilkan proses demokrasi yang unik, dimana hasil Pilgub dalam 2 (dua) periode didominasi oleh tokoh atau figur yang sama. Jika kita runut dalam pesta demokrasi tersebut, terdapat sengketa yang cukup pelik diantara kedua kompetitor yang bersaing. Pada waktu itu ada satu calon yang sudah maju sebagai calon gubernur sebanyak dua periode dan Khofifah mengalami kekalahan 
dari Sukarwo. Pada kesempatan yang ketiga, kandidat tersebut kembali mencalonkan diri, namun dalam Pilkada yang akan dilaksanakan pada 2018, kandidat tersebut didukung oleh mantan pesaingnya di pilkada sebelumnya (Nazriyah, 2013).

Seiring dengan perjalanan waktu, telah muncul dua kandidat kuat yakni Syaifullah Yusuf dan Khofifah. Masing-masing dari mereka terus melakukan pergerakan. Hasil Pilkada sebelumnya merupakan barometer untuk mengukur kekuatan masing-masing calon. Ada sedikit perubahan dari pergerakan tokoh-tokoh yang dulunya menjadi satu koalisi saat ini menyebrang dan pindah haluan, dimana tokoh-tokoh tersebut memiliki basis massa dan kekuatan politik, sehingga perlu adanya kalkulasi ulang terkait hasil pemilihan gubernur periode sebelumnya.

\section{Pergerakan dan Koalisi Saifullah Yusuf dan Khofifah Indar Parawansa}

Pergerakan dua kandidat utama, pada pertengahan tahun 2018 belum begitu terlihat, dimana Syaifullah Yusuf serta Khofifah Indar Parawangsa beberapa hasil survei belum tampak melabuhkan diri pada partai tertentu, namun demikian beberapa partai sudah mulai angkat bicara dengan kemungkinan-kemungkinan yang bisa terjadi dalam kompetisi Pilgub Jawa Timur 2018.

Banyak prediksi yang menyebutkan akan semakin memanas persaingan itu. Khofifah Indar Parawansa akan kembali maju untuk yang ketiga kalinya, beberapa partai pun telah menunjukan sinyal dukungannya, salah satunya Partai Nasional Demokrat (Surabaya.com, 15 Agustus 2018).

Gambar 4. Pemberitaan terkait Pengusungan calon gubernur oleh partai NASDEM

\section{Khofifah Siap Dimajukan}

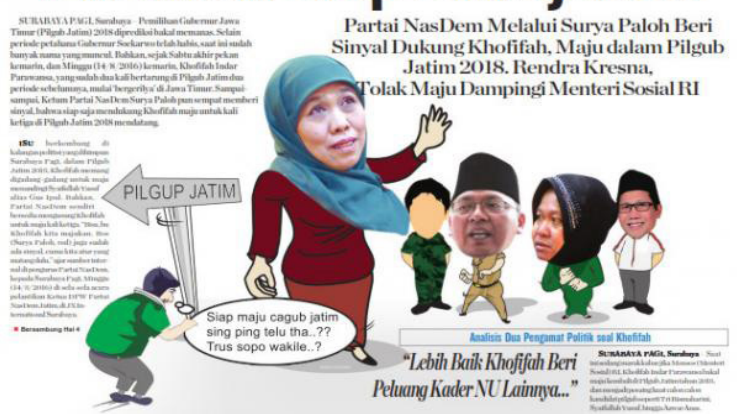

Sumber:Surabaya.com, 15 Agustus 2018.
Pada Mei 2017, DPD Partai Golongan Karya Jatim memberi sinyal dukungan pencalonan untuk bakal calon gubernur. Nama yang disebutkan ini adalah Wakil Gubernur Jawa Timur Syaifullah Yusuf. Dukungan ini diberikan dengan pertimbangan sosok dan figur Syaifullah Yusuf yang dinilai sudah teruji memimpin Jawa Timur. Namun itu masih sebatas wacana, karena situasi politik selalu berubah-ubah. (Jurnal13.net, 21 Maret 2017).

Sementara itu, PAN siap mengusung Khofifah Indar Parawansa atau Syaifullah Yusuf. Meski Begitu PAN tetap menunggu keputusan dari Presiden Joko Widodo apakah memberi persetujuan kepada Khofifah yang merupakan menterinya untuk maju menjadi calon Gubernur Jawa Timur (Kumparan.com, 27 Maret 2017).

Sekitar Mei 2017, PDIP Jatim melakukan survei di antara para kandidat yang muncul. Wali Kota Surabaya Tri Rismaharini dan Syaifullah Yusuf adalah dua nama yang dinilai terkuat yang saat ini masuk dalam lingkaran survei PDIP, namun akhirnya PDIP menetapkan calon lain setelah kandidat Azwar Anas mengundurkan diri (Surya.co.id, 06 Februari 2017).

Ketua umum DPP PKB, Muhaimin Iskandar, mengatakan telah menetapkan bakal calon gubernur yang akan diusung pada Pilgub Jawa Timur 2018. Nama Ketua DPW PKB Jawa Timur, Abdul Halim Iskandar atau Gus Halim menjadi kandidat yang akan dicalonkan. Tetapi rencana tersebut akhirnya di batalkan oleh Muhaimin. PKB pun akhirnya merapat ke kubu Safulloh Yusuf (Kompas.com, 26 Mei 2017).

Beberapa pernyataan dan juga rumor yang berkembang dikalangan politikus termasuk partai politik, menggambarkan bahwa bursa pencalonan calon gubernur Jawa Timur mulai digodok di internal partai. Proses tersebut masih mencoba mempertimbangkan berbagai aspek, keuntungan, dan juga kelemahan, para kandidat. Akibatnya, proses musyawarah dapat mendapatkan kata sepakat terkait bakal calon gubernur dan wakil gubernur 2018-2023. Secara umum, partai melirik dua kandidat kuat yang namanya beredar kepermukaan yaitu Syaifullah Yusuf dan Kofifah Indar Parawangsa. Walaupun muncul kandidat lain, seperti Tri Rismaharini, hal ini disebabkan karena ia merupakan kader partai PDIP yang memiliki basis masa militan di Jawa Timur dan memiliki track record serta 
popularitas yang tinggi.

Peta koalisi partai politik yang akan mengusung calon gubernur dan wakil gubernur, bisa terlihat jelas, setelah masing-masing partai berkomitmen dengan membuat keputusankeputusan utama dengan mengusung calon tersebut baik menjadi satu paket ataupun hanya memilih salah satu, karena, secara logika partai politik pasti akan memilih kawan koalisi yang menguntungkan dan memiliki haluan yang sama, dan kesempatan yang lebih besar.

Secara umum dua kandidat, Syaifullah Yusuf dan juga Kofifah Indar Parawangsa merupakan dua sosok yang kemungkinan besar akan di usung oleh partai politik besar atau minimal dengan koalisi yang kuat, namun saatitu partai politik masih menimbang serta menakar, sejauhmana kekuatan masing-masing kandidat, sehingga terdapat berbagai kemungkinan yang bisa saja terjadi tidak hanya itu salah satu aspek penting yang dipikirkan oleh partai adalah siapa sosok yang akan mendampingi kandidat tersebut.

Perjalanan koalisi yang terjadi pada dua calon pasangan ini ternyata menimbulkan persoalan baru. Pasangan Khofifah Indar Parawangsa akhirnya mengusung salah satu kader PDIPyang saat inimenjabat sebagai Bupati Kabupaten Trenggalek, yakni Emil Dardak, naiknya wakil dari Khofifah ini memunculkan persoalan, dimana partai besar yang dulunya mendukung Emil dalam Pilkada Kabupaten Trenggalek yakni PDIP menolak majunya Emil, karena PDIP memiliki kandidat sendiri yang rencananya akan di usung menuju kubu Syaifullah Yusuf. Calon tersebut adalah Azwar Anas Bupati Kabupaten Banyuwangi, yang memiliki rekam jejak yang menurut sebagian kalangan cukup baik diwilayah tersebut. Akan tetapi, muncul isu terkait adanya persoalan amoral yang dialami oleh Azwar Anas, dari isu yang berkembang, rupanya Syaifullah Yusuf mengganti kandidat wakil gubernur menuju Tri Rismaharini atau bahkan figur yang lain.

Terjadi persoalan ketika Emil Dardak diusung kepada Partai Demokrat untuk mendampingi Khofifah. Meskipun secara teknis Dardak adalah kader PDI-P, hal ini sempat menimbulkan persoalan dan ketegangan, karena Partai Demokrat dianggap sebagai partai outsourcing yang mudah sekali mengangkat orang-orang sebagai kadernya (news.detik.com, 26 November 2017).

Beredar isu setelah mundurnya Azwar
Anas, salah satunya adalah sosok Tri Rismaharini sebagai penggantinya, namun demikian di beberapa kesempatan Tri menolak tawaran tersebut, sehingga PDIP dan PKB berupaya keras untuk memperoleh kandidat lain (kompas. com, 5 Januari 2018).

Selain dua pristiwa besar tersebut, ada beberapa pristiwa yang menggemparkan bursa calon kandidat pada Pilgub Jawa Timur 2018, diantaranya tidak jadinya PKB mengusung Halim yang merupakan adik dari ketua PKB, Muhaimin Iskandar, selain itu ada beberapa gebrakan yang coba dilakukan, misalnya mengerucutnya dukungan Partai Demokrat ke kubu Khofifah. Disini ada indikasi jika pembina Partai Demokrat menyerukan supaya seluruh kader Partai Demokrat Jawa Timur merapat ke Kubu Khofifah.Tentu secara nalar tidak bisa digambarkan, mengingat ketika Pilgub Jawa Timur sebelumnya, Partai Demokrat merupakan salah satu partai pengusung Sukarwo dan Syaifullah Yusuf, namun politik adalah kepentingan, dimana Partai Demokrat menilai jika Khofifah memiliki kans lebih besar untuk memenangkan Pilkada ini.

Disisi lain Partai Gerindra yang pada awalnya akan mengusung La Nyala Matliti, ternyata Gerindra, PAN, dan PKS sedang menyiapkan strategi untuk mengusung kadernya untuk maju sebagai kandidat, terdapat beberapa calon kandidat yang mencuat diantaranya Kang Nyoto salah satu tokoh besar di Jawa Timur, Anang Hermansyah Politisi dari PAN, Moreno Soeprapto anggota DPR RI asal Kota Malang.

PKB yang selama ini bersikeras untuk mengusung Halim sebagai calon Gubernur Jatim, akhirnya mengubah dukungannya kepada Syaifullah Yusuf. Hal ini diperkuat oleh pernyataan ketua Umum nya Muhaimin Iskandar, beliau menyampaikan permohonan maaf kepada pendukung halim yang kebetulan adalah kakak kandung ketua PKB (kompas. com, 29 April 2017).

Partai Demokrat ternyata mengirim sinyal yang cukup kuat, untuk mengusung Khofifah dalam Pilgub Jawa Timur 2018, hal itu ditegaskan oleh Dewan Pembina Partai Demokrat E.E. Mangindaan. Hal ini atas gagasan Pakde Karwo, selaku ketua DPD Jawa Timur (Tempo.co, 5 Oktober 2017).

Partai Gerindra bersama PAN dan PKS mengindikasikan membuat keputusan terkait kemungkinan membuat poros baru. Hal ini setelah mundurnya La nyala Mataliti 
sebagai salah satu kandidat, namun demikian, kemungkinan ini masih bisa berubah, mengingat ke tiga partai ini belum memiliki figur kuat yang bisa di majukan dalam Pilkada nanti (cnnindonesia.com, 30 Desember 2017).

\section{Peran Media dalam Pembentukan Opini Publik}

Perlu diketahui bahwa dalam upaya melaksanakan strategi dan marketing politik media memiliki posisi penting, disinilah media memberikan pendidikan politik serta memberikan arahan serta mempengaruhi khalayak untuk memilih kandidat tertentu, selain itu, disini peran media merubah paradigma atau cara berfikir masyarakat dalam melakukan penilaian. Di Jawa Timur, ada beberapa raksasa media yang kita ketahui diantaranya Jawa Post dan Kompas. Dua media ini memiliki pengaruh dan peran dalam kehidupan sehari-hari mengingat sebanyak 33 kabupaten/kota di Jawa Timur setiap hari menyaksikan pemberitaan ataupun warta dari media tersebut, jadi penting untuk bermitra dengan media tersebut.

Pemanfaatan media juga dioptimalkan melalui pembuatan single album kampanye yang dilakukan oleh kedua calon. Genre musik yang digunakan menggunakan pop dan dangdut "koplo" yang banyak di gemari oleh masyarakat di Jawa Timur. Berbagai artis juga di daulat sebagai juru kampanye dari masingmasing kandidat sebagai salah satu strategi untuk mensosialisasikan program dan calon supaya lebih dikenal oleh masyarakat. Kedua pasangan calon ini tahu betul bagaimana media membantu mempengaruhi publik, sehingga mulai gencar dilakukan berbagai kampanye secara masif melalui jaringan internet yang dianggap lebih efektif.

Menurut peneliti, pasangan Syaifullah Yusuf lebih bisa membaca peluang dan memanfaatkan media, dalam periode waktu sebelum pencalonan, Syaifullah Yusuf memanfaatkan aktris dan penyanyi terkenal untuk mempengaruhi kalangan muda, melalui album kampanye yang di bawakan oleh artis dangdut dari Jawa Timur.

\section{Analisis Peta Politik Kandidat PilgubJawa Timur 2018}

Melihat beberapa pertimbangan yang terkait dengan kandidat Syaifullah Yusuf, serta Khofifah Indar Parawangsa, secara umum memang berbagai lembaga survei ataupun media, telah mengeluarkan hasil penilaian terkait peluang kedua calon tersebut jika maju di Pilgub Jatim 2018, namun demikian perlu di pahami bahwa belum rampunya kesepakatan antar partai pengusung dari kedua kandidat tersebut, sehingga masih ada kemungkinankemungkinan koalisi yang sama seperti budaya wilayah atau bahkan berbeda dari kondisi yang umum, sementara partai yang dominan di Jawa Timur PKB sudah menentukan calon, sehingga hal tersebut bisa mengurangi suara dan juga kekuatan kedua calon tersebut.

Selain itu partai PDIP juga sedang melakukan penjaringan calon yang salah satunya memunculkan nama Walikota Surabaya Tris Rismaharini. Partai ini memiliki basis masa yang kuat, sehingga perlu juga menjadi perhatian, sehingga salah satu cara yang paling tepat untuk menggalang dukungan adalah sesegera mungkin menjajaki koalisi supaya jelas partai pengusung sehingga bisa memetakan kekuatan secara nyata. Partai koalisi pemenang pengusung gubernur pada periode sebelumnya, merupakan partai yang bisa dijadikan salah satu kendaran mengingat beberapa partai yang mengusung calon tersebut belum menentukan kiblat dan koalisi, sehingga bisa menjadi peluang. Penekanan yang coba kami sampaikan adalah keberadaan politik identitas yang menjadi budaya masyarakat Jawa Timur selama ini, sehingga potensi dalam memetakan persiangan menuju Jawa Timur Satu tetap didomonasi oleh budaya dan struktur lama yang memiliki akar rumput dan fanatisme.

Pada koalisi PDIP dan PKB yang dulunya tidak mendukung Syaifullah Yusuf sekarang merapat ke koalisi tersebut. Latar belakangnya merupakan salah satu mantan Ketua GP Anshor yang merupakan salah satu tokoh dikalangan NU. PDIP akhirnya mengusung Puti Guntur Soekarno pengganti dari Azwar Anas. Kelemahan yang paling terlihat adalah ketika calon wakil yang sudah di gadang-gadang mendampingi Syaifullah Yusuf bermasalah terkait adanya kasus amoral. Koalisi yang dahulu mengusung Syaifullah Yusuf dan Pakde Karwo beralih untuk mendukung Khofifah, seperti partai demokrat.

Pada koalisi Partai Demokrat, Partai Nasdem, Partai Persatuan Pembangunan, Partai Hanura, Partai Golkar, PAN, dan Partai Gerindra. Khofifah merupakan salah satu pimpinan fatayat dan muslimat $\mathrm{NU}$ yang memiliki basis masa besar khususnya di Jawa 
Timur. Pasangannya Emil Dardak memiliki kelemahan bermasalah dengan partainya, yaitu PDIP.

Kendati demikian, terdapat kekuatankekuatan lokal yang saling bersaing. Selain itu, hal ini juga berkaitan dengan strategi dan pengusungan kandidat untuk kepentingan Pemilu Presiden 2019. Jika kita perhatikan secara seksama, koalisi ini secara umum menggambarkan tentang adanya blok-blok partai yang dahulu berkoalisi ketika Pilpres 2014, yang tercermin pada Pilgub Jawa Timur 2018.

Tabel 1. Peta Koalisi Pilgub Jawa Timur

\begin{tabular}{cll}
\hline No & Koalisi Partai & \multicolumn{1}{c}{ Kandidat } \\
\hline $\mathbf{1}$ & $\begin{array}{l}\text { Partai Demokrat } \\
\text { Partai Nasdem } \\
\text { PP Partai Hanura } \\
\text { Partai Golkar } \\
\end{array}$ & $\begin{array}{l}\text { Khofifah Indar P } \\
\text { (Ketua) } \\
\text { PAN }\end{array}$ \\
& Grindra & \\
$\mathbf{2}$ & PDIP & \\
& PKB & Syaifullah Dardak (Wakil) \\
& PKS & (Ketua) \\
& & Azwar Anas (gagal) \\
& & Tri Risma Harini \\
& & (gagal) \\
& & Puti Guntur S (Wakil) \\
\hline
\end{tabular}

Sumber: Olahan penulis

Situasi politik yang semakin mengerucut akhirnya membentuk pola koalisi apalagi setelah koalisi antara Partai Gerindra, PAN dan PKS tidak menemukan kesepakatan, kemudian, bentuk koalisi partai mengerucut kepada kedua calon, pertama adalah Khofifah Indar Parawangsa dan Emil Dardak. Kemudian calon yang kedua adalah Syaifullah Yusuf dengan Puti Guntur Soekarno, walaupun pada awalnya kesulitan menemukan kandidat pengganti Azwar Anas pada akhirnya menemukan Puti Guntur Soekarno yang memiliki trah dari Sukarno sebagai salah satu tokoh nasional yang memiliki pendukung dan basis massa di Jawa Timur. Hal ini menegaskan bahwa Koalisi PDIP dan PKB menginginkan perolehan suara mutlak dari para simpatisannya, sehingga Puti dianggap bisa mewakili keinginan para pendukung Sukarno.

\section{SIMPULAN}

Melihat kondisi di atas disimpulkan beberapa hal penting yang bisa menjadi bahan pertimbangan bersama untuk kedua calon kandidat tersebut, khususnya yang terkait dengan pemetaan kekuatan, kelemahan, peluang, serta ancaman, yang muncul seiring dengan perkembangan waktu. Poin pentingnya ialah bahwa Jawa Timur yang menjadi salah satu basis suara dari partai $\mathrm{PKB}$, yang berangkat dari budaya NU dan partai sudah menentukan sikap untuk mengusung pasangan calon Syaifullah Yusuf. Namun demikian di kubu lainnya, yakni Khofifah, yang sama-sama kader dari organisasi NU, dengan latar belakang Muslimat NU, memungkinkan perolehan suara dari kedua calon tersebut bakal terbagi atau terpecah, sehingga tidak dapat maksimal. Salah satu upaya yang bisa dilakukan adalah dengan mencari restu kiai untuk memaksimalkan mobilisasi warga nahdiyin yang akan menjadi salah satu lumbung suara.

PDIP yang awalnya mengusung Azwar Anas, untuk mendapingi Syaifullah Yusuf diprediksi akan mengganti kadernya, karena adanya indikasi bahwa Azwar Anas terlibat kasus amoral, akhirnya menentukan pilihan kepada Puti Guntur Soekarno yang merupakan salah satu keturunan Seokarno. Sebagai salah satu tokoh yang memiliki kharisma dan pendukung loyal di Jawa Timur, kendati demikian, figur yang diusung ini kurang mempunyai daya tarik, sehingga banyak pihak akan memeperebutkan basis-basis suara partai PDIP, mengingat massa PDIP merupakan masa yang cukup besar terutama di wilayah Mataraman. Kemungkinan Partai Demokrat sebagai koalisi dari Khofifah akan bekerja keras memecah basis massa PDIP di wilayah tersebut.

Pasca mundurnya La Nyala Mataliti yang akan di usung oleh gerindra, maka partai Grindra, PAN dan PKS sempat berencana membentuk poros barudengan rencana mengusung beberapa kandidat, seperti Sunyoto, Anang Hermansyah dan Moreno Soprapto yang memiliki rekam jejak cukup bagus di Jawa Timur, selain itu tiga partai ini juga memiliki basis massa karena PAN identik dengan budaya organisasi Muhammadiyah (walaupun bukan organisasi politik), selain itu PKS memiliki basis massa di wilayah perkotaan yaitu kalangan Islam modern, sedangkan Partai Gerindra merupakan partai baru yang memiliki simpatisan yang loyal dan bercorak nasionalis seperti PDIP. Namun demikian seiringnya perkembangan waktu ternyata poros ini tidak cukup kuat sehingga melebur pada dua koalisi besar yang sudah mengusung Syaifullah Yusuf dan Khofifah. 
Pihak Khofifah sangat di untungkan dengan merapatnya Partai Gerindra dan PAN ke koalisi tersebut.

Potensi pemanfaatan media oleh para kandidat selain dengan pemanfaatan media seperti Jawa Post dan Kompas, media sosial seperti Youtube akan menjadi sarana kampanye yang dianggap efektif untuk mempengaruhi khalayak yang ada di Jawa Timur. Apalagi dilibatkannya artis ataupun penyanyi yang memiliki basis penggemar yang banyak akan menambah semarak pertarungan pemilihan gubernur 2018 ini, di sini Syaifullah Yusuf lebih bisa membaca peluang, terkait menarik simpati anak-anak muda melalui public figure artis populer.

Aspek paling penting lainnya yang perlu dilakukan oleh kandidat adalah segera menentukan dan membentuk strategi politik dengan memanfaatkan sumberdaya manusia termasuk basis massa serta menggunakan pendekatan budaya. Dengan demikian basis massa bisa di pengaruhi untuk memilih kandidat, Oleh karena itu diperlukan pembacaan dan analisis yang tajam dari tim sukses terkait kondisi dan realitas yang ada di Jawa Timur, karena masing-masing koalisi dan calon pasangan memiliki daya tarik serta kelebihan dan juga kelemahan.

\section{DAFTAR PUSTAKA}

Abdurrahman. (2009). Fenomena Kiai Dalam Dinamika Politik: Antara Gerakan Moral dan Politik. karsa , 2524.

Bachri, B. S. (2010). Meyakinkan Validitas Data Melalui Triangulasi Pada Penelitian Kualitatif. Jurnal Teknologi Pendidikan, 46-62.

Beritasatu.com. (19 Desember 2015). "PDIP Klaim Kemenangan Mayoritas di Pilkada Jatim”, diakses pada 18 mei 2017,http:// www.beritasatu.com/nasional/329420pdip-klaim-kemenangan-mayoritas-dipilkada-jatim.html

Cnnindonesia.com.(30Desember2017)“Koalisi Gerindra, PAN, PKS Siapkan Kejutan di Pilkada Jatim", diakses pada 06 Januari 2018 https://www.cnnindonesia.com/ nasional/20171229220056-32265646/ koalisi-gerindra-pan-pks-siapkankejutan-di-pilkada-jatim
Hamil, Mohd Faidz Mohd Zain Jamaie Hj. Razak, Mohd Rizal Mohd Yaakob Mohamad Rodzi Abd. (2011). Pengaruh nasionalisme melayu mewarnai budaya politik melayu dalam UMNO. Jurnal Melayu, 193-216

Herdiansah, A.G, Putri, D.A., Ashari, L., dan Maduratmi, R. (2017). "The Islam Defence Action: A Challenge of Islamic Movement to Democratic Transition in the Post 2014 Indonesia." Jurnal Wacana 20 (2): 57-67.

Jatim.bps.go.id. (18 April 2017). "Peta Persebaran Wilayah Provinsi Jawa Timur badan pusat statistik Jawa Timur" diakses pada 18 Mei 2017 https://jatim. bps.go.id

Jawapos.com. (28 April 2017). Data The Intiactive Institute "Hasil Survei Pilgub Jatim 2018 Saifullah yusuf dibayangi khofifah dan risma", diakses pada 16 Mei 2017 http://www.jawapos.com/ $\mathrm{read} / 2017 / 04 / 28 / 126338 /$ Syaifullah -yusuf-dibayangi-khofifah-dan-risma

Ja'far, S. (2012). Politik Kaum Santri Dalam Sejarah Indonesia . Review Politik, 265281.

Jurnal3.net (21 Maret 2017). "DPD Golkar Jatim beri sinyal usung Gus Ipul", diakses pada 17 Mei 2017, https:// jurnal3.net/2017/03/21/dpd-golkarjatim-beri-sinyal-usung-gus-ipul/

Kompas.com. (26 Mei 2017). PKB, "Holopis Kuntul Baris", dan Pilkada Jawa Timur 2018, diakses 06 Januari 2018, http://sains. kompas.com/read/2017/05/26/05440061/ pkb.holopis.kuntul.baris.dan.pilkada.jawa. timur.2018.

Kompas.com, (29 April 2017), 'PKB Akan Usung Gus Halim pada Pilkada Jatim 2018", diakses pada 17 Mei 2018 http:/nasional.kompas. com/read/2017/04/29/18441801/pkb.akan. usung.gus.halim.pada.pilkada.jatim.2018

Kompas.com.(21 Juli2008) “KualiPeleburan di Tlatah Jawa Timur", diakses pada 13 Mei 2017. http://nasional.kompas. $\mathrm{com} / \mathrm{read} / 2008 / 07 / 21 / 00594333 /$ kuali.peleburan.di.tlatah.jawa.timur

Kompas.com. (02 Mei 2014). "Menakar "Koalisi Semangka" Jokowi vs Prabowo 
diakses pada 10 Mei 2017http://nasional. kompas.com/read/2014/05/02/0839135/ Menakar.Koalisi.Semangka.Jokowi. vs.Prabowo

Kompas.com. (05 Januari 2018). "Risma Bakal Gantikan Posisi Azwar Anas sebagai Cawagub Jatim?", diakses pada 06 Januari 2018, http://nasional.kompas. $\mathrm{com} / \mathrm{read} / 2018 / 01 / 05 / 14143601 /$ rismabakal-gantikan-posisi-azwar-anassebagai-cawagub-jatim

Kompas.com. (18 Mei 2018). "Hasil Pemilu Jawa Timur", diakses dari diakses pada 13 Mei 2017, http://assets.kompas.com/ data/photo/2013/08/19/1458333201308 18H24P-ARS-PilkadaJatim780x390.jpg

Kpujatim.go.id. (3 Mei 2016). "Persiapkan Pilkada 2017 \& 2018, Kpu Jatim Berikan Pembinaan Jabatan Fungsional", diakses pada 13 Mei 2017, http://kpujatim. go.id/berita-kpu-jatim/persiapkanpilkada-2017-2018-kpu-jatim-berikanpembinaan-jabatan-fungsional/

Kumparan.com. (27 Maret 2017). "Zulkifli Hasan: PAN Usung Khofifah dan Gus Ipul di Pilgub Jatim", diakses pada 17 mei2017, https://kumparan.com/ananda-wardhiatiteresia/zulkifli-hasan-pan-usung-khofifahdan-gus-ipul-di-pilgub-jatim

Liliana, N.R. (2014). Strategi Komunikasi Pemasaran Politik Dalam Kampanye Calon Legislatif (Caleg) Terpilih Partai Persatuan Pembangunan (Ppp) Dalam Pemenangan Pileg 2014 Kota Pekanbaru. JOM FISIP , 1 - 11.

Nazriyah, R. (2013). Dinamika Pemilihan Gubernur Jawa Timur. Hukum IUS IUSTUM, 641-665.

News.detik.com. (26 November 2017). "Soal Khofifah-Emil Dardak, PDIP: SBY Terapkan Politik Outsourcing", diakses pada 06 Januari 2018 https:// news.detik.com/berita/3744170/ soal-khofifah-emil-dardak-pdip-sbyterapkan-politik-outsourcing

Nu.or.id. (18 April 2018), “Syuriyah PWNU Jatim Bantah Fatwa Haram Perempuan Jadi Pemimpin" diakses pada 29 Mei 2017, http://www.nu.or.id/post/ $\mathrm{read} / 12052 /$ syuriyah-pwnu-jatim- bantah-fatwa-haram-perempuan-jadipemimpin

Paradhisa, N.Z. (2012). Konflik Kepentingan Daerah: Studi Kasus Sengketa Perebutan Gunung Kelud Antara Pemerintah Kabupaten Kediri Dan Pemerintah Kabupaten Blitar. Polit Muda , 136 146.

Pontoh, M.R.C. (2015). Strategi Kampanye Pemenangan Bupati Dan Wakil Bupati Terpilih Pada Pemilihan Kepala Daerah Kabupaten Minahasa. Acta Diurna, 1-16

Rasaili, W. (2016). Budaya Politik dan Kwalitas demokrasi dalam Pilkada 2015-2020 (Studi pada Pemilihan Kepala Daerah Serentak Pertama di Indonesia). ARISTO, 4(2), 1-13.Doi: http://dx.doi.org/10.24269/ars.v4i2.185

Surabayapagi.com. (15 Agustus 2016). "KhofifahSiapDimajukan", diaksespada 17 mei 2017 http://www.surabayapagi. $\mathrm{com} / \mathrm{read} / 140365 / 2016 / 08 / 15 /$ Khofifah_Siap_Dimajukan.html

Surabayapagi.com. (15 Agustus 2016), "Pemberitaan terkait Pengusungan calon gubernur oleh partai NASDEM", diakses pada17Mei2017http://www.surabayapagi. com/read/140365/2016/08/15/Khofifah_ Siap_Dimajukan.html

Surabaya.tribunnews.com. (06 Februari 2017). "Survei Internal PDIP Jatim, Ada Nama Selain Risma dan Gus Ipul untuk Bakal Calon Gubernur", diakses pada 17 Mei 2017 http://surabaya.tribunnews. com/2017/02/06/survei-internal-pdipjatim-ada-nama-selain-risma-dan-gusipul-untuk-bakal-calon-gubernur

Taufiqurrahman. (2007). Identitas budaya madura. Karsa , 1 - 11.

Tempo.com. (05 Oktober 2017). "Dewan Pembina Demokrat Beri Sinyal Dukungan ke Khofifah", diakses pada 06 Januari 2018 https://nasional.tempo.co/read/1022351/ dewan-pembina-demokrat-beri-sinyaldukungan-ke-khofifah

Wurianto, A.B. (2012). Model kecerdasan kultural dalam pengembangan content pendidikan karakter pada pendidikan dasar. Politik, 1-16. 